Institute of $\mathbf{F}_{\text {ood and }} \mathbf{A}_{\text {gricultural }} \mathbf{S}_{\text {ciences }}$

\title{
Cultural Guidelines for Commercial Production of Interiorscape Dracaena 1
}

\author{
Dennis B. McConnell, Jianjun Chen, Richard J. Henny, and Kelly C. Everitt ${ }^{2}$
}

Dracaena, a genus in the family Agavaceae, is composed of about 40 species. Unlike most monocots, Dracaenas are evergreen shrubs or trees most frequently characterized by long linear leaves often on unbranched stems or trunks. Mature heights reach from two to over 50 feet. One species, $D$. americana, is indigenous from Mexico to Costa Rica; all other species are native to Africa, India, Madagascar, or islands in the South Pacific. Cultivated species, excluding $D$. draco that may be grown for its red resin, are grown for their ornamental value. This article describes common species and cultivars in the foliage plant industry (See Table 1), provides guidelines on their culture and interior use, and lists physiological problems that may be encountered in both production and interiorscape use (See Table 3).

\section{Cultural Guidelines}

\section{Propagation}

Rooting of tip cuttings, air layering, and cane cuttings are the primary methods of Dracaena propagation. Air layering or cane cuttings are mainly used for large specimens, and tip cuttings are used for producing the smaller Dracaena species.

\section{Production}

Sphagnum peat, pine bark, vermiculate, or perlite (leach before using) can be volumetrically combined to formulate media for plants in smaller containers while media for larger plants may contain $10-20 \%$ coarse sand to keep plants from wind tipping. Media should have good moisture capacity and aeration, soluble salts of $1-2 \mathrm{dS} / \mathrm{m}$, and $\mathrm{pH}$ of 6.0 to 6.5. A pH lower than 6.0 may cause leaf chlorosis while a media $\mathrm{pH}$ above 6.5 will cause iron deficiency.

Dracaena sp. should be grown in a shadehouse with a temperature of 70 to $90^{\circ} \mathrm{F}$ and a relative humidity of 60 to $100 \%$. Temperatures above $90^{\circ} \mathrm{F}$ cause foliar chlorosis of 'Janet Craig' and notching of 'Warneckii'. Controlled-released or water-soluble fertilizers with micronutrients or a combination of both can be used for Dracaena production. Fertilizers with low boron and fluoride levels and an N:P:K ratio of 3:1:2 or 3:1:3 are best. The suggested application rate is $3 \mathrm{lb} \mathrm{N}$ per 1,000 sq. $\mathrm{ft}$ per month. Table 2 provides a guide for determining if Dracaenas are

1. This document is ENH892, a series of the Environmental Horticulture Department, Institute of Food and Agricultural Sciences, University of Florida. Please visit the EDIS web site at http://edis.ifas.ufl.edu. Original publication date: April 2003.

2. Jianjun Chen, Assistant Professor, Mid-Florida Research and Education Center and Environmental Horticultural Department, Dennis B. McConnell, Professor, Environmental Horticultural Department, Richard J. Henny, Professor, Mid-Florida Research and Education Center and Environmental Horticultural Department, and Kelly C. Everitt, Research Assistant, Mid-Florida Research and Education Center at the Institute of Food and Agricultural Sciences, University of Florida.

The Institute of Food and Agricultural Sciences is an equal opportunity/affirmative action employer authorized to provide research, educational information and other services only to individuals and institutions that function without regard to race, color, sex, age, handicap, or national origin. For information on obtaining other extension publications, contact your county Cooperative Extension Service office. Florida Cooperative Extension Service/Institute of Food and Agricultural Sciences/University of Florida/Christine Taylor Waddill, Dean. 
appropriately fertilized based on leaf analysis.

Fertilization should be reduced by $50 \%$ or stopped one month before shipment.

Dracaenas for interior use should be grown under shade. D. arborea, fragans, and marginata can be grown under 63 to $73 \%$ shade (3250 to $4000 \mathrm{fc}$ ) and the other species under 73 to $80 \%$ shade (2500 to $3250 \mathrm{fc})$. Although the yellow color of 'Massangeana' and the red tones in D. maginata cultivars increase with higher light, the variegation percentage in other Dracaena will decrease if grown under shade levels lower than $80 \%$.

\section{Shipping and Interior care}

Dracaena should be shipped at temperatures between 55 and $65^{\circ} \mathrm{F}$. Once plants are placed indoors, it is advisable not to re-pot or fertilize for about four weeks because plants do not need additional stress. Plants should not be fertilized if soluble salts are 1.0 $\mathrm{dS} / \mathrm{m}$ or more. If soluble salts levels are higher than $3.0 \mathrm{dS} / \mathrm{m}$, percolation of the media with water may help reduce potential leaf burning problems. Media should be kept moist. Temperatures of 70 to $80^{\circ} \mathrm{F}$ are most appropriate, and drafts should be avoided. (See Table 3) 
Table 1. A listing of Dracaena cultivars and species available in Florida as of 2002.

\begin{tabular}{|c|c|c|}
\hline Species & Cultivar or Common Name & Characteristics \\
\hline D. arborea & 'Tree Dracaena' & $\begin{array}{l}\text { Mature plants may grow to } 30-40 \text { feet tall, } \\
\text { usually multi-branched with } 3 \text {-foot-long linear } \\
\text { leaves. }\end{array}$ \\
\hline D. deremensis & $\begin{array}{l}\text { 'Gold Star', 'Janet Craig', 'Janet Craig } \\
\text { Compacta', 'Lemon Lime', 'Lisa', } \\
\text { 'Michiko', 'Warneckii', 'Warneckii } \\
\text { Jumbo' }\end{array}$ & $\begin{array}{l}\text { Although this plant can grow to heights of } 15 \\
\text { feet, most interiorscape specimens are less } \\
\text { than } 10 \text { feet. Typically plants have long } \\
\text { narrow leaves clustered on an unbranched } \\
\text { stem. Leaves of most common cultivars have } \\
\text { longitudinal stripes of various shades of } \\
\text { green, cream, white, or yellow. }\end{array}$ \\
\hline D. fragrans & $\begin{array}{l}\text { 'Green Corn Plant', 'Massangeana', } \\
\text { 'Character', 'Santa Rosa' }\end{array}$ & $\begin{array}{l}\text { Usually grown and sold in containers with } \\
\text { multiple woody canes of different lengths up to } \\
15 \text { feet tall. A single cluster of long linear } \\
\text { leaves tops each cane. The leaves are mostly } \\
\text { solid green while 'Massangeana' has as a } \\
\text { broad, bright yellow central stripe. 'Character' } \\
\text { plants are branched. }\end{array}$ \\
\hline $\begin{array}{l}\text { D. marginata or } D \text {. } \\
\text { concinna }\end{array}$ & $\begin{array}{l}\text { 'Madagascar Dragon Tree', 'Bicolor', } \\
\text { 'Character', 'Colorama', 'Exotic', } \\
\text { 'Madagascar', 'Magenta', 'Tricolor' }\end{array}$ & $\begin{array}{l}\text { Young plants are single stemmed but can be } \\
\text { induced to branch and are sometimes trained } \\
\text { to have bent or character stems. The narrow, } \\
\text { linear, deep green leaves have red, narrow } \\
\text { margins. The various cultivars have } \\
\text { additional maroon or magenta colors in the } \\
\text { leaves. }\end{array}$ \\
\hline D. reflexa & $\begin{array}{l}\text { 'Malaysian Dracaena', 'Song of } \\
\text { India', 'Song of Jamaica' }\end{array}$ & $\begin{array}{l}\text { Short linear leaves on single stems when } \\
\text { young, these plants usually branch when } \\
\text { reach three feet high. The species has deep } \\
\text { green leaves but the cultivars have attractive } \\
\text { variegated foliage. }\end{array}$ \\
\hline D. sanderiana & $\begin{array}{l}\text { 'Ribbon Plant', 'Gold', 'Lucky } \\
\text { Bamboo' }\end{array}$ & $\begin{array}{l}\text { Typically single stemmed, but the stems } \\
\text { never become strong enough to remain } \\
\text { upright beyond 2-3 feet in height. The short, } \\
\text { linear, green leaves have light yellow margins } \\
\text { that are more intense in the cultivar 'Gold'. } \\
\text { 'Lucky Bamboo' plants are typically leafless } \\
\text { stems of 'Ribbon Plant' sold individually or in } \\
\text { clusters. }\end{array}$ \\
\hline D. surculosa & 'Junita' & $\begin{array}{l}\text { Mature specimens of this native of tropical } \\
\text { Africa may attain heights of five feet, but } \\
\text { interiorscape specimens of this shrubby, } \\
\text { multi-branched Dracaena are typically } 2-3 \text { feet } \\
\text { tall. The ovate leaves are dark green and } \\
\text { thickly mottled with creamy white blotches. }\end{array}$ \\
\hline Dracaena Ricki & 'Ricki' & $\begin{array}{l}\text { This cultivar is of uncertain parentage but it } \\
\text { resembles a cross between } D \text {. deremensis } \\
\text { and } D \text {. marginata. Some growers believe it is } \\
\text { a sport of } D \text {. deremensis. }\end{array}$ \\
\hline
\end{tabular}


Table 2. Nutrient concentrations in leaves considered low, medium, and high for Dracaena growth.

\begin{tabular}{||l|l|l|l||}
\hline \hline Nutrient & Low & Medium & High \\
\hline Nitrogen (\%) & $<2$ & $2.0-3.5$ & $>3.5$ \\
\hline Phosphorus (\%) & $<0.15$ & $0.15-0.4$ & $>0.4$ \\
\hline Potassium (\%) & $<2.0$ & $2.0-3.5$ & $>3.5$ \\
\hline Calcium (\%) & $<1.0$ & $1.0-2.5$ & $>2.5$ \\
\hline Magnesium (\%) & $<0.2$ & $0.2-1.0$ & $>1.0$ \\
\hline Sulfur (\%) & $<0.2$ & $0.2-0.75$ & $>0.8$ \\
\hline Iron (ppm) & $<40$ & $50-300$ & $>300$ \\
\hline Manganese (ppm) & $<35$ & $50-300$ & $<300$ \\
\hline Zinc (ppm) & $<15$ & $20-200$ & $>200$ \\
\hline Copper (ppm) & $<7$ & $8-50$ & $>50$ \\
\hline Boron (ppm) & $<19$ & $20-50$ & $>50$ \\
\hline \hline
\end{tabular}

Table 3. Causes and effects of various physiological problems.

\begin{tabular}{|c|c|c|}
\hline Symptoms & Cause & Treatment \\
\hline $\begin{array}{l}\text { Chlorotic banding of } D \text {. } \\
\text { marginata leaves. }\end{array}$ & $\begin{array}{l}\text { Exposure to } 32-37^{\circ} \mathrm{F} \text { for several } \\
\text { hours. }\end{array}$ & Avoid low temperatures. \\
\hline $\begin{array}{l}\text { Leaf tips or margins become } \\
\text { chlorotic or necrotic. }\end{array}$ & $\begin{array}{l}\text { High boron, fluoride, or soluble } \\
\text { salts. Media } \mathrm{pH} \text { may be too low. }\end{array}$ & $\begin{array}{l}\text { Damaged leaves will not recover. } \\
\text { Leach media to lower high } \\
\text { soluble salts. Adjust media } \mathrm{pH} \text { to } \\
6.5 \text { and use fertilizers and water } \\
\text { low in boron and fluoride. }\end{array}$ \\
\hline $\begin{array}{l}\text { Yellowing of leaves with green } \\
\text { veins creating a netted } \\
\text { appearance. }\end{array}$ & $\begin{array}{l}\text { Temperatures above } 90^{\circ} \mathrm{F} \text { and } \\
\text { low available iron. }\end{array}$ & $\begin{array}{l}\text { Lower media } \mathrm{pH} \text { to } 6.0 \text {; increase } \\
\text { shade levels if in a production } \\
\text { area. Drench with iron chelate. }\end{array}$ \\
\hline $\begin{array}{l}\text { Slimy, necrotic spots on leaves, } \\
\text { mass leaf drop. }\end{array}$ & Chilling injury. & $\begin{array}{l}\text { Plants should be kept in areas } \\
\text { above } 60^{\circ} \mathrm{F} \text { at all times, } \\
\text { including shipping and } \\
\text { showcasing. }\end{array}$ \\
\hline $\begin{array}{l}\text { Spear becomes hard and may } \\
\text { not open, notably in } D \text {. marginata } \\
\text { particularly in winter. }\end{array}$ & Copper deficiency. & $\begin{array}{l}\text { Spray with copper-based } \\
\text { fungicide. }\end{array}$ \\
\hline $\begin{array}{l}\text { Severe leaf distortion, } \\
\text { particularly in highly variegated } \\
D . \text { marginata. Notching in } \\
\text { 'Warneckii'. Poor head } \\
\text { development in 'Massangeana'. }\end{array}$ & Boron deficiency. & $\begin{array}{l}\text { Spray with borax. Leaves will not } \\
\text { recover. }\end{array}$ \\
\hline
\end{tabular}


Table 3. Causes and effects of various physiological problems.

\begin{tabular}{|c|c|c|}
\hline Symptoms & Cause & Treatment \\
\hline $\begin{array}{l}\text { New leaves on } D \text {. marginata are } \\
\text { pale with green transverse veins. }\end{array}$ & Manganese deficiency. & Spray with manganese chelate. \\
\hline $\begin{array}{l}\text { Loss of yellow stripe in } \\
\text { 'Massangeana'. Narrower than } \\
\text { normal leaves. }\end{array}$ & Nitrogen deficiency. & $\begin{array}{l}\text { Be wary of the root system. } \\
\text { Spray with calcium nitrate or urea. }\end{array}$ \\
\hline Older leaves will turn purple. & Phosphorus deficiency. & $\begin{array}{l}\text { Common in soils high in } \\
\text { aluminum. Increase phosphorus } \\
\text { in fertilizer. }\end{array}$ \\
\hline Tipburn in older leaves. & Sodium toxicity. & $\begin{array}{l}\text { Increase potassium and top dress } \\
\text { with gypsum. Usually a result of } \\
\text { high salinity in irrigation waters. }\end{array}$ \\
\hline Reduced leaf size. & Zinc deficiency. & $\begin{array}{l}\text { Spray with chelated zinc. } \\
\text { Affected leaves will not recover. }\end{array}$ \\
\hline Flowering. & Abnormal flowering. & $\begin{array}{l}\text { Usually caused by cooler, wet } \\
\text { weather. An increase in nitrogen } \\
\text { helps keep it at bay. }\end{array}$ \\
\hline Abnormally narrow leaves. & Strap-leaf. & $\begin{array}{l}\text { Root disease or poorly aerated } \\
\text { soil. Repot into fresh media. }\end{array}$ \\
\hline Leaves curl. & Leaf curl. & $\begin{array}{l}\text { A temporary condition brought on } \\
\text { by high light and/or temperature. } \\
\text { As light or temperature is } \\
\text { reduced, the leaves will return to } \\
\text { normal. }\end{array}$ \\
\hline $\begin{array}{l}\text { Sunken, rust-colored areas } \\
\text { appear on leaves usually near } \\
\text { the tips. }\end{array}$ & Sunburn. & $\begin{array}{l}\text { Remove the plant from the } \\
\text { affecting light and gently trim the } \\
\text { damaged areas. }\end{array}$ \\
\hline
\end{tabular}

